\title{
Proposal for a National Earthquake Insurance Programme for Greece
}

\author{
Aglaia Petseti and Milton Nektarios \\ Department of Statistics and Insurance, University of Piraeus, 80 Karaoli \& Demitriou street, \\ Piraeus 18534, Greece. \\ E-mails: nektar@unipi.gr; aglaia.petseti@gmail.com
}

It is proposed that Greece undertakes the establishment of a national earthquake insurance programme for homeowners that will replace the ex post disaster relief by the State when an earthquake occurs. Greece is seismically the most active region in the whole Mediterranean. By employing four different catastrophe models, it has been estimated that the economic loss to the residential stock of a 1-in-200 year event is likely to be greater than 22 billion euros; for a 1-in-100 year event is about 14 billion euros; for an 1-in-25 year event is 5 billion euros; and for a 1 -in- 5 year event is 1.3 billion euros. This potential loss severity exposes the inherent limitations of the ex post funding approach to natural disasters adopted by successive Greek governments and underscores the urgent need for establishing a National Earthquake Insurance Programme. It is proposed that the earthquake coverage should be compulsory and the management of the insurance programme be based on the principle of a public-private partnership. The objective of the programme would be to provide affordable earthquake insurance, up to a maximum amount, to all homeowners, on the basis of risk-based premiums. A comprehensive and unique data bank of the residential stock in the country has been developed, which will be very useful to the local insurance industry as well as to reinsurers.

The Geneva Papers (2012) 37, 377-400. doi:10.1057/gpp.2012.12

Keywords: earthquake insurance; homeowners; catastrophe modelling; compulsory insurance; reinsurance markets

\section{Earthquake risk in Greece: vulnerability and mitigation measures}

Greece is vulnerable to a number of physical disasters; however, earthquake hazard is the most significant in terms of magnitude and frequency of losses and casualties. Greece and its surrounding areas is seismically the most active region in the whole Mediterranean and West Eurasia. According to seismologists half of the energy released annually by earthquake activity on the European continent is taking place in Greece. Greece also holds the sixth place regarding seismic exposure on a worldwide level, following Japan, Vanuatu, Peru, Salmon Islands and Chile. ${ }^{1}$

Since 1900, more than 60 earthquakes have taken place in Greece; 40 of them caused considerable human casualties. ${ }^{2}$ It has been estimated that during the last three

\footnotetext{
${ }^{1}$ Tsapanos and Burton (1991).

${ }^{2}$ Institute of Geodynamics (2006); National Observatory of Athens (2006).
} 
decades the total economic loss from earthquakes was approximately $€ 10$ billion. $^{3}$ During this period, three notable earthquakes have occurred $(1981,1995,1999)$, with little impact on the insurance market; the first affected 80,400 people, the second affected 45,300 people, and the third 115,139 people (www.preventionweb.net).

The most damaging seismic event has been the earthquake of Athens in 1999. This was an earthquake of a medium magnitude (5.9R); however, it resulted in 143 deaths and 1,600 injuries. The economic loss of this earthquake was about $€ 3.5$ billion, in 1999 prices. ${ }^{3}$ The major part of this loss was undertaken by the public budget; during the period 1999-2003, the State paid $€ 839,000,000$ in loans and subsidies to households as well as in infrastructure projects. The insured claims amounted to $€ 130$ million; in the residential sector, there were 6,800 claims, whereas in the industrial sector claims amounted to no more than 10 per cent of the total number of claims, but the insured losses were almost half of the total losses paid by the insurance industry. ${ }^{3}$

The 1999 earthquake provoked a short-lived political reaction in the form of legislation that would create a national earthquake insurance organisation; this legislation was soon abandoned. The institutional setting for seismic risk management has been simple: the public administration deals with the consequences of earthquakes only when an earthquake occurs; then, ex post financing is raised in a haphazard way and subsidised loans are made available to affected citizens or outlays are made for repairing public infrastructure. This practice cannot work anymore, because the public finances of the country do not allow any margin for extra expenses to finance catastrophe losses, in the present or in the future. This study reveals that the potential for a serious earthquake loss is substantial. It is necessary for the country to organise an integrated risk management plan, which will involve all major stakeholders: the government, the public administration, the insurance industry and the citizens. The main part of this risk management system should be the proposed national earthquake insurance programme.

The main contributions of this study are (a) to create a comprehensive and unique data bank of the residential stock in Greece, which will be valuable to the local insurance industry and reinsurers as well, (b) to estimate the potential earthquake loss exposure by employing all major international catastrophe models, and (c) to propose an innovative national earthquake insurance programme.

In a country where earthquakes have caused massive property damage throughout history, it might be expected that insurance would be a priority for homeowners. While the last major earthquake did lead to an increase in the take-up of insurance, most people put their faith in the State to look after them in the event of another major earthquake. Property insurance penetration is still below 20 per cent and only 60 per cent of property policies cover the risk of earthquake. In the aftermath of the 1999 earthquake, larger commercial and industrial companies have come to appreciate insurance, although smaller and medium-sized enterprises remain underinsured; this development has created a substantial loss exposure for local insurers. Insurance companies could suffer substantial losses, in spite of the low insurance penetration,

\footnotetext{
${ }^{3}$ AICG (2001).
} 
if a moderate or stronger earthquake would strike again; by using a catastrophe insurance model, it has been estimated that the insurance industry would have to pay claims in the range of $€ 1$ billion in insured losses, if an earthquake like the 1999 one were to occur today (see section "Modelling earthquake risk for Greece").

So far, the Greek State has followed the post-event approach to disaster funding. This includes increasing taxes, reallocating funds from other budget items, accessing domestic and international credit, and borrowing from multi-lateral finance institutions. Pursuing a post-disaster financing strategy has several disadvantages, well-known in the insurance economics literature. ${ }^{4}$ Clearly, there is significant value in shifting the traditional "disaster relief" approach-raising scarce funds after the event hits - to an approach that accumulates funds and funding sources before a disaster occurs. The financial and insurance markets can play a key role in preparing for the impact of extreme natural events and can also help to spread risks. No country can fully insulate itself against extreme events. A new generation of sovereign insurance instruments can make it easier for national governments to cope with disasters. ${ }^{5}$

We suggest that it is time for Greece to establish a modern integrated risk management programme for the catastrophe risk of earthquakes. Neighbouring countries have already set up such schemes (Turkey) or are exploring the possibility of creating a reinsurance facility (www.europa-re.com) with the help of international institutions. ${ }^{6}$

In this paper we propose an earthquake insurance programme for the residential sector in Greece. This approach does not disregard the significance of insuring other important costs, like in infrastructure, business, health, etc., but the emphasis is placed on the protection of households. To that end a unique data bank of the residential properties in Greece has been compiled; this is going to turn out to be an important contribution to the local insurance industry as well as to the reinsurers.

The data set is based on the latest Census of $2000^{7}$; additional and more recent and refined data were derived from the records of the National Tax Authority (unpublished data). The 2000 Census provides information regarding the number of buildings, their usage, year built, construction material, number of residencies, number of stories and allocation of buildings by post code. The data derived from the National Tax Authority provides the most detailed and recent information in respect of the number of residencies, their surface and their construction year. The information provided by the National Tax Authority is comprehensive and overcomes the problem of unregistered residential properties, which was widespread in the past.

Detailed analysis of the available data shows that there are 3,867,340 residential buildings, 90 per cent of which are used for housing purposes only, while the remaining 10 per cent includes stores and offices apart from houses. The total number of residencies in the entire building stock is 7,504,240 and the total value of this

\footnotetext{
${ }^{4}$ Kunreuther et al. (1978); Kunreuther (1984, 1996); Lewis and Nickerson (1989); Zeckhauser (1995).

5 Nektarios (2011).

${ }^{6}$ Gurenko (2006); Gurenko et al. (2006).

${ }^{7}$ NSSG (2000).
} 
portfolio is estimated to amount to $€ 905,953,097,503^{8}$ (both building and content accounted). According to these estimates, there has been a 26 per cent and a 33 per cent increase in the number of buildings and residencies, respectively, during the last decade. ${ }^{9}$ The value of residential buildings in the Metropolitan Area of Athens represents 35 per cent of the total residential stock.

Certain very important conclusions may be derived from a careful analysis of the data. First, it is estimated that 21 per cent of the residencies in Greece were constructed before 1960; this fact implies that approximately 1,500,000 households do not have access to private insurance because the local insurance market does not provide insurance cover to houses that have been built prior to year 1960. Second, it is estimated that residences in Greece have an average surface area of 85 square metres(sq.m). Third, buildings consist of a small number of floors; half of the buildings are ground floor constructions and most apartment buildings with over three floors are built in the Metropolitan Area of Athens. Fourth, the majority of houses, 59 per cent of total, are located in the low-risk seismic Zone I, 40 per cent of houses are built in the medium-risk seismic Zone II, and just 1 per cent is located in the high-risk seismic Zone III. ${ }^{10}$ Finally, it may be noted that the first earthquake building code came into force in 1959 and has been regularly updated, most recently with the Greek Earthquake Resistant Code 2000; it is not known what percentage of the buildings need reinforcement to withstand a major earthquake.

In the next section, an international review of insurance schemes for mitigating the earthquake risks is undertaken. In the third section, we analyse the economic principles that justify government involvement in the provision of earthquake insurance. In the fourth section, we estimate the expected losses from an earthquake in Greece, by employing four alternative catastrophe models. In the fifth section, the analysis of the third section is used to design the proposed National Catastrophe Insurance Programme for Greece. The conclusions follow in the final section.

\section{Insurance schemes for mitigating the catastrophe risk: an international review}

When countries encounter high uninsured losses due to a catastrophic event, their economies can be stunted. The essential question is whether the private insurance industry can reasonably handle future catastrophe risks. There are different views on whether private insurance and reinsurance markets have adequate capacity to cover the risk of mega-catastrophes. It is true that reinsurance capacity can significantly

\footnotetext{
${ }^{8}$ Value per building=average number of houses per building $\times$ average area per house in sq. $\mathrm{m} \times € 1.100$ ( $€ 1.100$ is the average reconstruction value per sq.m, used by the insurance industry).

Value per content $=$ average number of houses per building $\times$ average area per house in sq. $\mathrm{m} \times € 400$ ( $€ 400$ is the average contents value per sq.m, used by the insurance industry).

${ }^{9}$ This data set is a best estimate. The derived portfolio is a hypothetical residential buildings portfolio for the entire Greek territory and no liability is assumed if this data set is found different in any future census or research.

${ }^{10}$ A new map of seismic hazard zones is applicable since 1995 by the Greek State. This map distributes all areas of the Greek territory in three seismic Zones I, II and III, according to low, medium and high exposure, respectively.
} 
drop after one or more major events, but capacity typically rebounds after the events. In fact, Guy Carpenter ${ }^{11}$ estimated that the reinsurance sector was overcapitalised by $\$ 20$ billion at the beginning of 2010 , causing 21 reinsurers to return capital to shareholders. It is also true that the price of reinsurance increases when the industry is hit by severe catastrophe losses, but the price of reinsurance typically falls after capacity is increased. The Rate-on-Line (ROL) increased from 150 in 1999 to 260 in 2003, then fell to around 225 in 2005 and then increased to 300 in 2006 after the 2004-2005 hurricane seasons. It then fell again to 250 in $2010 .{ }^{11}$ While this pattern does reflect volatility in reinsurance prices, it seems that this volatility has been substantially lower during the last decade even with the very high catastrophe losses in 2001, 2004, 2005 and 2008.

In the last two decades catastrophe (CAT) bonds have been used to tap the much broader capacity of financial markets. This means that there is reason to be sceptical about arguments that there is insufficient private capital to cover the risk of natural catastrophes. Therefore, the widespread government involvement in the provision of catastrophe insurance must be based on other arguments. In the next section, we argue that the most compelling argument for a government-driven catastrophe insurance system would be that it could be designed to encourage (or even compel) adequate catastrophe risk coverage for most or all property owners, provide appropriate incentives for mitigation, and reduce the risk of insolvency for insurance and reinsurance companies that cover catastrophe risks.

In practice, without the right insurance or other funding mechanisms in place, societies recovering from catastrophes must deplete public and private reserves, levy taxes, borrow extensively, or become reliant on the mercy of the international community. Countries vary a great deal in how they manage and insure against catastrophes. Key considerations include: (a) income available to spend on insurance or save in disaster funds, (b) the availability of affordable insurance coverage, (c) awareness of the scale and scope of possible catastrophes, (d) implementation and enforcement of appropriate building codes, (e) access to global risk transfer markets, (f) the effectiveness of public-private risk transfer partnerships. ${ }^{12}$

If a country's individuals and government do not have the means to purchase insurance, then insurance and reinsurance mechanisms will not be in place. In poor countries, the gap between insured and economic losses is enormous. In Haiti, the 2010 earthquake caused economic losses that amounted to 123 per cent of GDP, but only 3 per cent was insured; in China, the 2008 Sichuan earthquake generated $\$ 366$ million in insured losses, compared with an economic loss of $\$ 125$ billion; in Chile, the 2010 earthquake caused economic losses of 15 per cent of GDP, and 27 per cent of them were insured. ${ }^{12}$

However, even in highly developed countries, insurance for catastrophic perils is not always adequate or available due to market conditions. In the United States, flood risk is insured through the National Flood Insurance Programme; yet, flood insurance often is not purchased, can be expensive in high-risk areas, and can include multiple

\footnotetext{
${ }^{11}$ Guy Carpenter (2010).

12 Best's Review (2011).
} 
exclusions. Rate subsidies are limited to residential and commercial properties that were built in high-risk areas prior to 1974. In Japan, the 2011 Tohoku earthquake caused an economic loss of 4 per cent of GDP, but only 14 per cent of it was insured; the latter is mainly due to the tsunami effects, although only 40 per cent of Japanese residencies have earthquake insurance. ${ }^{12}$ The conclusion is that it can be difficult for individuals to see the value of purchasing insurance against events that may not happen within their lifetimes. In the next section we analyse the conditions under which governments may play a significant role by requiring insurance or levying taxes or fees that are used to build up disaster relief funds.

In this context, it is useful to provide an overview of the government catastrophe insurance schemes in the world. ${ }^{13}$

The first group includes countries that use tax revenues to establish pre-funded disaster-relief funds. Such countries are: Australia, Denmark, Mexico, the Netherlands, Norway and Poland. In these countries the government provides compensation only for losses that cannot be insured privately.

Spain has established government insurance programmes to provide coverage for natural disasters. The government scheme collects all premiums and accepts all risks ("premium pool"), while private insurers market the policies and handle claims settlement and other administrative details. The catastrophe coverage is mandatory and is provided as a rider to private property policies.

In France and Japan, the government acts as a reinsurer. Catastrophe coverage is mandatory and is added-on to property insurance policies; premium surcharges are set by the government. All catastrophe insurance written by private insurers is reinsured with the government reinsurance company, which essentially serves as a reinsurer of last resort.

Switzerland mandates natural catastrophe coverage but does not provide any explicit government financial guaranty. In the United Kingdom, flood coverage is typically included in private property insurance policies.

In the U.S., the States intervene in the private insurance market in order to secure catastrophe coverage at affordable prices for windstorms (in the South) and for earthquakes (in the West). The federal government has provided subsidised flood insurance since 1968 and entered the market for terrorism insurance as reinsurer of last resort in 2002. Recently, the federal government is exploring the issue of establishing a comprehensive national plan for natural catastrophe risks. ${ }^{14}$

A review of international experience with catastrophe risks reveals that 16 OECD countries have enacted a variety of programmes to manage the economic consequences of catastrophic events. ${ }^{15}$ The programmes differ in their structure as well as on the underlying premises of the nature of the risk. It is suggested that Greece follows the paradigm of other developed nations and designs and implements a generic catastrophe insurance programme, on the basis of the experience of other nations. We outline such a programme in the fifth section.

\footnotetext{
${ }^{13}$ Gurenko (2004); OECD (2005); GAO (2005).

${ }^{14}$ (NAIC, 2009).

${ }^{15}$ Freeman (2004).
} 


\section{Market failures and government insurance for earthquakes}

In the previous section we described a broad spectrum of government programmes aiming to provide catastrophe insurance, where the state participates as either a primary insurer or a reinsurer. In this section, we shall examine two relevant issues: first, what are the market failures that cause the uninsurability of the earthquake risk; and second, the need and the form of government involvement.

There is an extensive insurance literature concerning insurance market failures in providing insurance for catastrophes. Gron ${ }^{16}$ and Froot ${ }^{17}$ argue that there is evidence of market failures in case of catastrophic risks, whereas Cummins et al. ${ }^{18}$ and Cummins $^{19}$ argue that the private sector-including reinsurance and the nascent catastrophe-linked securities market — can be expected to provide adequate coverage at affordable premiums for mega-catastrophes. Litan ${ }^{20}$ believes that there is a kind of market failure in the case of catastrophe risks that only a formal government reinsurance programme can remedy; only if the government takes on this role, it will in the long run minimise the costs it bears for disaster relief and the large social costs that natural disasters inevitably impose on the private sector. The academic debate has been going on with analyses of issues that affect both the demand and the supply side. $^{21}$

The insurance literature has extensively analysed the causes of the limited insurability of the catastrophe risk, in general, and of the earthquake risk, in particular. More recent works have provided a systematic analysis of the uninsurability issue and have shown that this issue may be due to: (a) issues of adverse selection and moral hazard, (b) supply-side problems, and (c) demand-side restrictions. ${ }^{22}$

The problem of adverse selection, which is the result of information asymmetries between the insured and the insurer, creates cross-subsidisation among the insureds. However, in the case of large-scale natural events, like earthquakes, information on the probability and severity of the event is public rather than private. The problem of adverse selection may be overcome by employing risk-based premiums and making insurance compulsory. ${ }^{23}$

The problem of moral hazard results in reduction of the incentives of individuals to undertake preventive actions in the design and construction of buildings. This problem may be overcome by setting official building standards that determine the resistance of the buildings in case of an earthquake. Picard ${ }^{24}$ has shown that prevention is improved if the government categorises individuals and areas and then charges risk-based

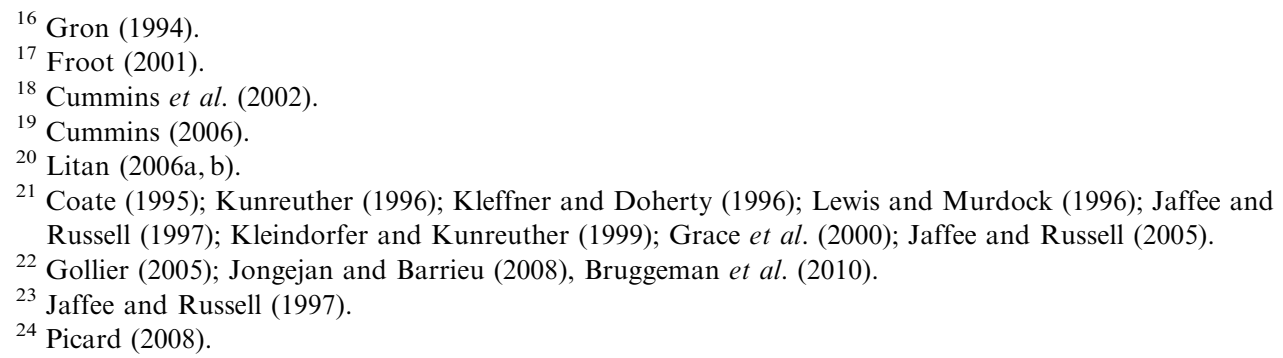


premiums to individuals and provides conditional grants to local communities to get involved in such prevention programmes.

The supply-side problems in the case of catastrophe/earthquake insurance are: (a) the high cost of primary insurance and reinsurance, (b) the fact that CAT bonds may be expensive, and (c) the low insurance capacity of local insurance markets.

The high cost of catastrophe/earthquake insurance is due to the high correlation of risks as well as to the "timing risk" (the possibility that the event occurs well before insurers have collected sufficient premiums to cover expected claims). Froot ${ }^{17}$ has demonstrated that in such cases the premiums are typically a multiple of expected losses. Primary insurers may overcome this problem by ceding the risk to reinsurers. But although reinsurers are able to spread the risk geographically, they would still face a relatively variable annual loss pattern due to the timing risk. It is reported that reinsurers of hurricane risks in the U.S. charged risk loads as high as five to six times expected losses. ${ }^{20}$

New capital market instruments have been developed in order to overcome the above problems of traditional insurance and reinsurance, such as CAT bonds. But so far, these securities have by no means driven the cost of coverage of catastrophe losses to expected loss, although a certain degree of convergence is observed between the spreads of CAT bonds and the price of reinsurance. ${ }^{25}$ Litan $^{20}$ argues that a major part of the high cost of CAT bonds is due to the timing risk, which is as much of a problem for buyers of CAT bonds as it is for primary insurers and reinsurers.

The limited capacity of the local insurance markets to cover the earthquake risk may be the most crucial factor for the uninsurability of this risk in less developed countries. In most cases the total equity of the local insurance market is a small percentage of the expected loss of a major catastrophe. But even in more developed insurance markets there might not be enough capacity; for example, the California Earthquake Authority operates as a direct insurer in the local market, in competition with private insurers.

Finally, there are demand-side restrictions that may explain the low demand for earthquake insurance coverage. The first restriction refers to the crowding-out of private insurance by solidarity and the provision of no incentives to take effective preventive measures. The provision of ex post relief will induce most people to remain uninsured and, therefore, "solidarity kills market insurance". ${ }^{26}$ Moreover, according to the expected utility model, a non-zero probability of post-disaster assistance reduces the amount of coverage that a person wishes to purchase as well as the incentive to take cost-effective mitigation measures. ${ }^{27}$ Notwithstanding the many arguments against ex post relief, governments can in practice not resist the temptation to provide generous amounts of relief after disasters have happened. ${ }^{28}$

The second reason for people's lack of interest in purchasing insurance against catastrophe risks seems to concern their perception of the probability of a

\footnotetext{
${ }^{25}$ Cummins (2008).

${ }^{26}$ Gollier, 2005).

${ }^{27}$ Priest (1996); Harrington (2000).

${ }^{28}$ Monti and Chiaves (2006).
} 
catastrophe. $^{29}$ When people place zero weight on the probability of suffering a loss, they will not consider an insurance purchase worthwhile, even when insurance is available at a subsidised rate; this result is consistent with experimental studies. $^{30}$

\section{Need and form of government involvement}

Given the market failures analysed above, the main issue is why the low level of insurance coverage is problematic for society. The basic argument concerns the costs of ex post relief programmes. Ad hoc responses by governments to disasters take place under tremendous time and political pressure and are therefore likely to be poorly targeted and inefficient. ${ }^{31}$

In a second-best world, government involvement would be required to remedy supply-side and demand-side failures and improve allocation of resources in the provision of earthquake insurance. The remedies should correspond to the market failures analysed above, and the government plans should mimic as closely as possible what operating private markets would have been expected to do. ${ }^{32}$ Bruggeman et al. ${ }^{33}$ have undertaken a detailed analysis of arguments against and in favour of government involvement in the provision of catastrophe insurance and have come up with certain conditions that render this involvement efficient. Accordingly, listed below are the main issues of government involvement in the provision of earthquake insurance.

\section{Main goals of government involvement}

The government would be required to move along two fronts: first, to provide underwriting capacity to overcome the problems on the supply-side; and second, to make earthquake insurance compulsory to prevent adverse selection and problems of low insurance penetration.

\section{Deductible}

A deductible is appropriate to prevent moral hazard. Different deductibles could be used for buildings and contents.

\section{Risk-based premiums}

A system of risk-based premiums will provide incentives to invest in cost-effective loss prevention measures.

\footnotetext{
${ }^{29}$ Kunreuther (1996); Kunreuther and Pauly (2006).

${ }^{30}$ Slovic (2000).

${ }^{31}$ Kunreuther (1996); Kunreuther and Pauly (2006); Thieken et al. (2006); Jongejan and Barrieu (2008); Cole et al. (2011).

32 Jaffee and Russell (2005).

${ }^{33}$ Bruggeman et al. (2010).
} 


\section{Efficient financing}

While the government's ability to diversify the earthquake risk cross-sectionally is limited, undoubtedly the government has a superior ability to diversify risks intertemporally, by regular borrowing or issuing CAT bonds.

\section{Public-private partnership}

International experience shows that all national catastrophe insurance schemes are based on some type of public-private partnership. A strong role for the government does not imply that there is no role for the private insurance industry. The private insurance industry could play two roles that could, but need not, be combined: (a) insurers could provide marketing/distribution and/or claims services and (b) insurers could provide underwriting capacity.

\section{The insurance role of the government}

There are three main alternatives for a potential public-private partnership in the provision of earthquake insurance. First, the government acts as a primary insurer; in this case the private insurance industry is limited in the provision of marketing and/or claims services. Second, private insurance offers some underwriting capacity, in addition to marketing and claims services. In this case there are two sub-options: the government may act as a "reinsurer of last resort" that sells reinsurance coverage for large losses, or it acts as a "backstop" that absorbs losses once the private insurance layer is exhausted.

These basic characteristics of the "optimal" government involvement in the insurance markets for catastrophe risks will be taken up in a later section to design the proposed national earthquake insurance programme for Greece.

\section{Modelling earthquake risk for Greece}

The ability to estimate the likelihood of catastrophes and prepare for them is paramount in minimising uninsured losses; the predictive capacity of the insurance industry increased greatly with the development of catastrophe modelling. ${ }^{34}$ In order to estimate the seismic hazard exposure for Greece, four internationally renowned models are used: RMS RiskLink version 9.0 (www.rms.com), AIR Clasic2 version 12.0.0 (www.air-worldwide.com), EQE Enterprise version 3.13 (www.eqecat.com), and IF Elements version 4.8.0.6 (www.aon.com). The actual operation of these models was undertaken by AON Benfield on the basis of the data bank provided by the authors. The input requirements for these models are the number of residential buildings according to year built, number of stories, construction type, and value of building and contents. All relevant information was classified per Catastrophe Risk Evaluating and Standardizing Target Accumulations (CRESTA) zone. Greece is divided into

\footnotetext{
${ }^{34}$ Grossi and Kunreuther (2005).
} 
16 CRESTA zones (www.cresta.org; www.oasp.gr); CRESTA zones are determined by postal code and region. Thus, the total national residential stock has been allocated according to: postal code, municipality, and CRESTA zone. This kind of information will prove to be extremely valuable to local insurers as well as to reinsurers.

The results of the four catastrophe models are presented in Table 1. Probable Maximum Losses (PML) in terms of Ground up Losses ${ }^{35}$ and Gross Losses ${ }^{36}$ have been estimated and are expressed as a percentage of Total Sum Insured. Table 1 refers to gross losses only. The models estimate the seismic risk of a structure, and the estimated loss is the combination of the seismic hazard at the site and the seismic vulnerability of the building. PML is the probable maximum loss for the portfolio of structures in a given time period; in other words, it is an estimate of the cost to restore the structures to pre-earthquake condition, expressed as a percentage of the replacement value.

PML limits are framed in terms of a return period. In this context, PML is defined as the largest likely loss to insured dwellings from an earthquake with a certain return period. A return period is an estimate of the interval of time between events, like an earthquake, of a certain intensity or size; it is a statistical measurement denoting the average recurrence interval over an extended period of time and it is the inverse of the probability that the estimated loss will be exceeded in any one year. If we take a 150 -year return period, the annual probability of loss from any single catastrophic event exceeding the given PML estimate would be 0.67 per cent. For this return period, the corresponding PML ranges between 1.03 per cent and 3.6 per cent of total sum insured, depending on the model used; this risk measure constitutes the most important risk charge of the pure premium of a catastrophic risk. This information will be very useful for the optimum design of the proposed National Catastrophe Insurance Programme in the next section.

By analysing the results of the four models, as presented on Table $1,{ }^{37}$ we may observe that a 5-year return period implies that losses of a certain amount have a probability of 20 per cent of occurring in any given year. Likewise, a 1-in-25 year earthquake is expected to generate losses with a 4 per cent probability of occurrence in any given year. If we take, for example, the results of the model IF ELEMENTS, the estimated gross loss is $€ 1,736,868,305$ for a 1 -in-5 year earthquake, and $€ 6,248,437,695$ for an 1-in-25 year earthquake, meaning that such losses have a 20 per cent and a 4 per cent probability of occurrence in any given year, respectively.

It is noteworthy that each one of the four catastrophe models provides significantly different results. This is due to the different structures and applications employed by each model. For instance, the model IF ELEMENTS, compared to all other three models, generates the highest gross losses up to 1-in-50 year return period. After this return period, it is the EQE model that generates the highest losses. Also, it is observed

${ }^{35}$ Ground up losses: total losses; no self-retention applies.

${ }^{36}$ Gross losses: retention is taken into consideration; retention is determined as 2 per cent of sum insured (building and content).

${ }^{37}$ Estimation of earthquake loss exposure is based on the analysis of Greek property data provided by the authors. No liability should be assigned to the enterprises: AON, EQECAT, AIR and RMS, as a result of the application of the four catastrophe models in this study. 


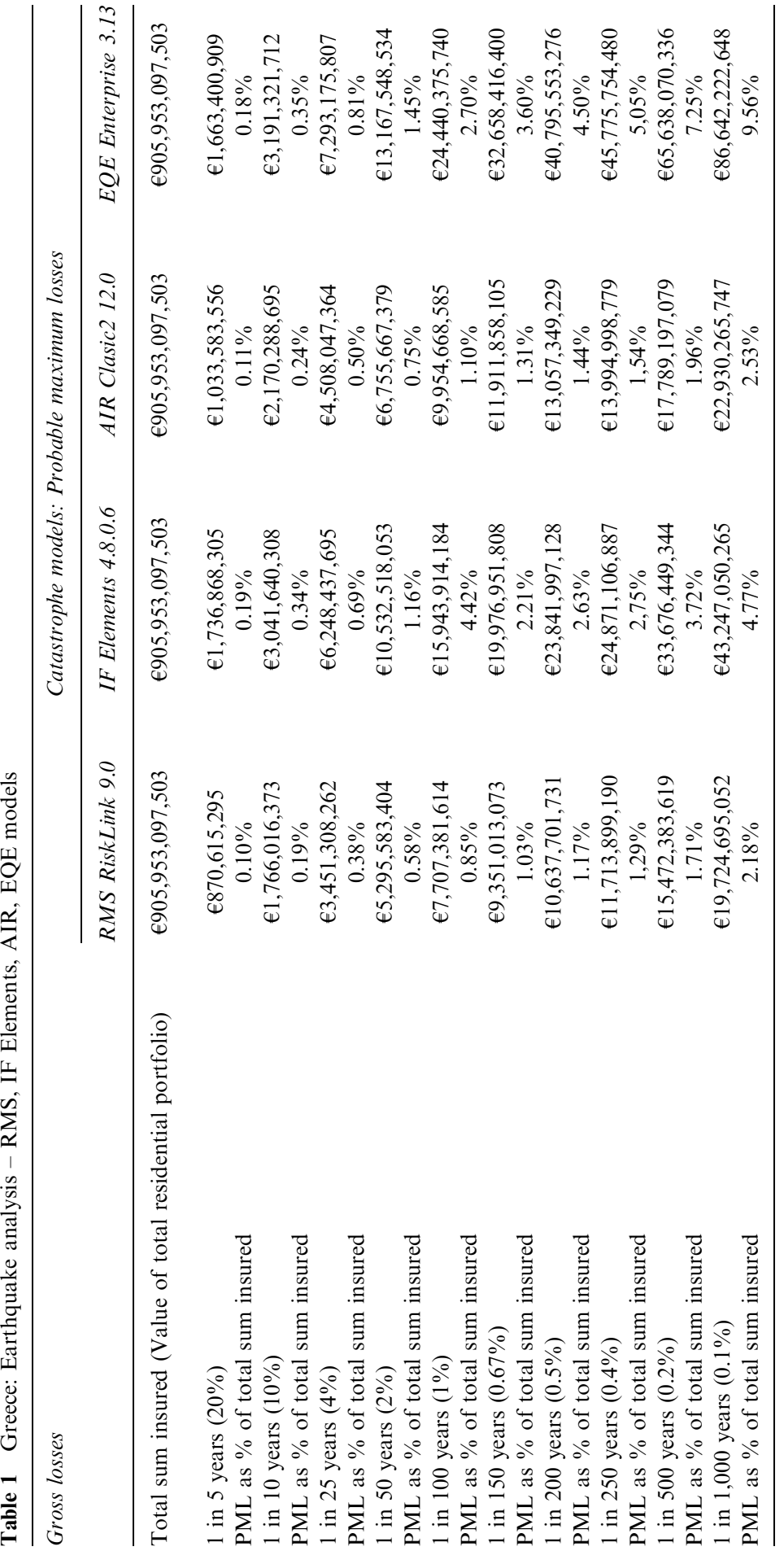




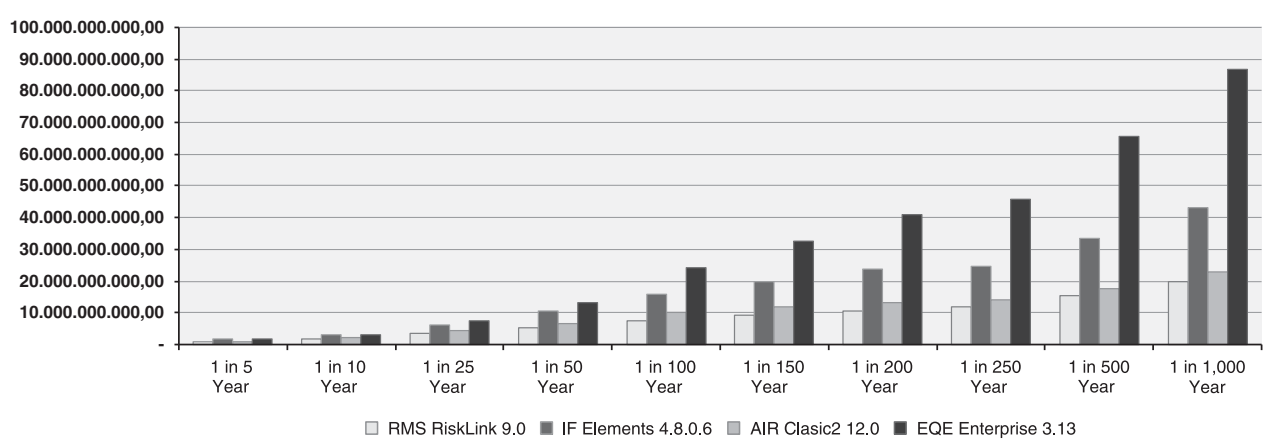

Figure 1. Gross losses for the four models: RMS, IF Elements, AIR, EQE (amounts in euros).

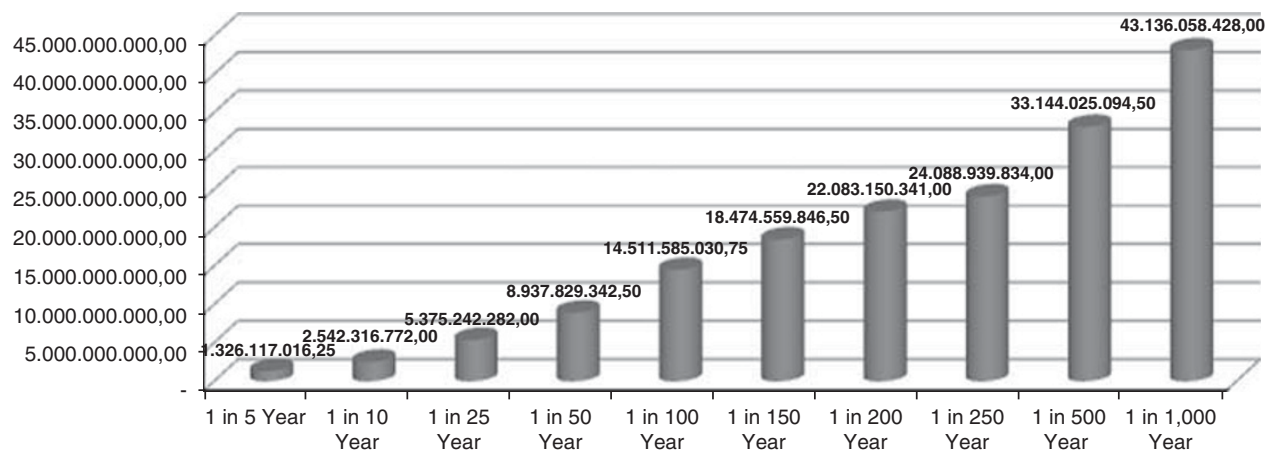

Figure 2. Average PML values (all models) per return period-Gross losses (€).

that the models RMS and AIR provide estimates in the lower range of the loss spectrum, whereas the two other models, IF ELEMENTS and EQE, provide estimates in the higher range. Figure 1 presents the results for gross losses per return period for all models.

In order to proceed with our analysis, we take the average value of the results of the four models and estimate an average value of PML for each return period. The average values of PMLs are presented on Figure 2.

On the basis of the values of Figure 3, we may estimate the aggregate Loss Exceedance Curve that allows quantification of maximum earthquake losses for a given return period. The values of the Exceedance Probability Curve are depicted on Figure 3 using the average results of all four models.

Table 2 presents the values of PMLs as percentages of the total value of all residential structures in Greece based on the average results of all four models. From Figure 2 and Table 2, it is observed that for return periods of 1-in-25 year, or 1-in50-year, or 1-in-100-year, the respective PMLs are 5 billion, 8.9 billion and 14.5 billion euros. These are magnitudes of expected losses that are beyond the fiscal capacity of the country to deal with; therefore, there is an urgent need for Greece to undertake a 
Exceedance Probability

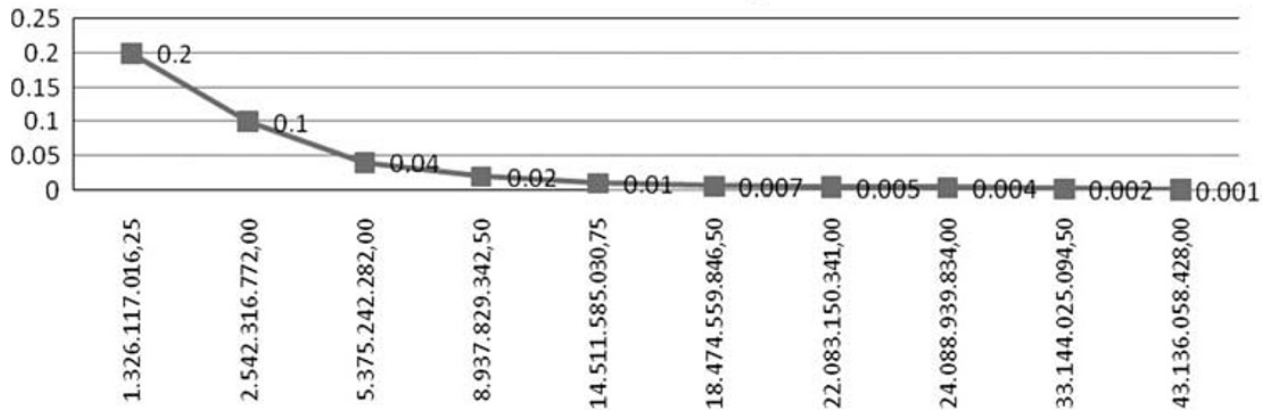

Figure 3. Exceedance probability curve (Gross losses; average of all models).

Table 2 PML as percentage of total residential value (average of all models)

\begin{tabular}{lcc}
\hline Return period & $\begin{array}{c}\text { Exceedance } \\
\text { probability }(\%)\end{array}$ & $\begin{array}{c}\text { PML as \% of total value - } \\
\text { gross losses (all models) }(\%)\end{array}$ \\
\hline 1 in 5 years & 20 & 0.10 \\
1 in 10 years & 10 & 0.30 \\
1 in 25 years & 4 & 0.60 \\
1 in 50 years & 2 & 1.00 \\
1 in 100 years & 1 & 1.60 \\
1 in 150 years & 0.67 & 2.00 \\
1 in 200 years & 0.50 & 2.40 \\
1 in 250 years & 0.40 & 2.70 \\
1 in 500 years & 0.20 & 3.70 \\
1 in 1,000 years & 0.10 & 4.80 \\
\hline
\end{tabular}

systematic approach to establish an integrated earthquake insurance scheme. We propose such a scheme in the next section.

\section{Proposal for a national earthquake insurance programme}

Greece must undertake a systematic risk management approach for the earthquake risk. Prevention and mitigation strategies must be the first priority in order to reduce the extent of economic loss and require the strong collaboration of all relevant parties, such as the public administration, the private insurance industry, the insurance intermediaries, and, mainly, the citizens; international experience with similar projects provides an abundance of "best practices" in this area.

In the framework of the overall risk management approach, the next step requires the design and implementation of an ex ante disaster financing mechanism for the residual risk. The analysis in the previous section shows that the potential economic losses to households from the earthquake risk is substantial in Greece. Successive governments have adopted reactive response approaches to natural disasters, as a 
consequence of the underdeveloped domestic insurance market and a lack of risk awareness.

The discussion in the third section has led to the description of the "optimal" characteristics of a government insurance programme for the earthquake risk. This discussion will provide the background for the derivation of the basic characteristics of the proposed programme for Greece. The most important choice involves the role of the government as insurer. International experience shows that, in general, governments have reacted to the uninsurability issue in two ways: either by creating the conditions for a private market to emerge, with the government acting as a reinsurer of last resort or as a backstop; or by establishing government-sponsored insurers to provide coverage. The former approach is usually associated with more developed insurance markets (with the exception of the California Earthquake Authority, which operates as a direct insurer). The latter approach is adopted mainly by countries with less developed insurance markets. The rationale of the latter approach has been adequately documented for the case of the Turkish Catastrophe Insurance Pool ${ }^{38}$ and is adopted here in proposing the establishment of the Greek Earthquake Insurance Programme. The overall core objectives of the national earthquake insurance programme should be as follows:

- Provision of affordable and effective basic (up to a maximum) earthquake insurance coverage, on a compulsory basis, to all residential houses, on the basis of risk-based premiums.

- Building a fund which is self-sustaining in the long run; that is, being capable of paying all insured losses from its reserves and reinsurance.

- Reduction of the government's obligation to provide post disaster emergency relief to the owners of residential houses.

- Provision of strong incentives for ex ante mitigation of loss exposures.

The success of the proposed national earthquake insurance programme depends on its efficient configuration and its effective implementation. The main characteristics of the proposed insurance programme are derived from the discussion in the third section and are outlined below.

\section{Legal framework}

The National Earthquake Insurance Programme should be a public-private partnership of the Greek state and the local insurance market. Its sole business objective should be to provide affordable earthquake insurance to all owners of residential housing, on a compulsory basis. Compulsory insurance eliminates adverse selection, maximises coverage and secures the diversification in the insurance portfolio. The rate of acceptance of the insurance programme by homeowners is crucial for its success. Some subsidisation may be necessary for very low income citizens and/or voluntary participation should be available for the owners of very old houses. On the other hand, the mandatory nature of the programme needs strict control and monitoring. Citizens

\footnotetext{
${ }^{38}$ Gurenko et al. (2006).
} 
should not be allowed to make any real estate transactions or apply for public utilities without providing insurance cover certificates. Another way to secure high participation in the programme is by requiring delivery of the insurance certificate annually when submitting the income tax statement. The most effective provision should be for the State to legislate that there will be no compensation or interest-subsidised loans to uninsured homeowners in case of an earthquake; but this requires a lot of political courage.

\section{Institutional structure}

A key policy issue in the design of the proposed insurance programme is to determine the appropriate roles for the Government, the domestic insurance companies and the reinsurers. The most important aspect of this structure, and the guarantee of its success, is the provision that the overall operational management of the programme be assigned to a major private insurance company, following a tender process. The Government will retain the audit function and overall regulatory oversight. The contractual responsibilities of the private operator should be to: (a) ensure policy issuance, marketing, premium collection and claims adjustments, (b) implement risk sharing and the reinsurance plan, (c) undertake sound investment policies of the reserves, and (d) carry out the public relations campaigns.

\section{Marketing and distribution issues}

The main goal in this context is to maximise the penetration of the insurance programme. The ideal solution would be to promote the standardised insurance policies through the facilities of the Public Electricity Company, which has a complete data bank of all residential houses with the corresponding surfaces; in this case, the calculation of the amount of the premium would be easy and it could be collected in quarterly instalments. Another option would be to use the insurance companies and their networks of insurance intermediaries; in this case, insurance penetration would be lower and costlier, as the experience of the respective Turkish programme shows. Nevertheless, in the following financial analysis of the programme, we allow for certain premium loading for insurers and intermediaries. In the early stages of the programme, significant expenses for marketing activities should be undertaken in order to inform the citizens about the scope and the objectives of the insurance programme.

\section{Insurance coverage terms and conditions}

The insurance programme should issue a stand-alone policy, which would not be part of any primary fire policy. Insurance cover provided by the programme would be compulsory only for homeowners and for every residence with a legal permit anywhere within the Greek territory. Insurance cover should be on a first loss basis, with a 2 per cent deductible. Under the compulsory programme, the residencies will be covered for material damages to building and content caused directly by an earthquake (including fires, explosions, and landslides following an earthquake). 
No cover will be provided for debris removal, business interruption, any loss of profit or income, other casualties, injuries or death, third-party liability, and any other indirect or consequential losses (these supplementary risks will be covered by private insurance).

\section{Limits of liability and premiums}

One of the main characteristics and advantages of compulsory insurance is the application of an affordable insurance premium; however, this premium still needs to be actuarially fair for citizens. The risk-based premiums will be differentiated for seismic Zones I, II and III, as well as according to construction year (before 1960, 1960-1985, 1986-1995, 1995+).

From Table 2, we observe that the PML for a return period of 1-in-50 years is 1.00 per cent of gross losses. We shall use this major component of the average annual expected loss as the benchmark for calculating indicative actuarial premiums for the proposed insurance programme. This approach may be refined significantly in a real situation, where more extensive periods of return or more variables may be adopted. Accordingly, we set the indicative net premium rate as shown on Table 3 . The net rates vary from $0.5 \%$ to $1.0 \%$. By applying policy fees ( 5 per cent) and overall commissions to insurance carriers and agents (20 per cent), we end up with the indicative gross premium rates on Table 4 .

Having set the premiums, the last step is to determine the limit of maximum insurance coverage. The "building sum insured" will be calculated as follows: [Surface in sq. $\mathrm{m} \times$ Construction Value]. Likewise, the "contents sum insured" will be: [Surface in sq.m $\times$ Contents Value]. Construction value has been set at $€ 1.100$ per sq.m, and contents value at $€ 400$ per sq.m. The average surface of all houses in Greece is 85 sq.m. We will use this average value to determine the maximum limit of liability provided by the compulsory insurance programme. Thus, the building sum insured is capped to: $€ 93.500$ [ $=85$ sq.m $\times € 1.100]$. The contents sum insured is capped to $€ 34.000$

Table 3 Indicative net premium rates

\begin{tabular}{|c|c|c|c|c|}
\hline & $<1960(\%)$ & $1960-1985(\%)$ & $1985-1995(\%)$ & $>1995(\%)$ \\
\hline Zone I & 0.080 & 0.070 & 0.060 & 0.050 \\
\hline Zone II & 0.090 & 0.080 & 0.070 & 0.060 \\
\hline Zone III & 0.100 & 0.090 & 0.080 & 0.070 \\
\hline
\end{tabular}

Table 4 Indicative gross premium rates

\begin{tabular}{|c|c|c|c|c|}
\hline & $<1960(\%)$ & $1960-1985(\%)$ & $1985-1995(\%)$ & $>1995(\%)$ \\
\hline Zone I & 0.100 & 0.088 & 0.075 & 0.063 \\
\hline Zone II & 0.113 & 0.100 & 0.088 & 0.075 \\
\hline Zone III & 0.125 & 0.113 & 0.100 & 0.088 \\
\hline
\end{tabular}


Table 5 Indicative gross premiums (euros)

\begin{tabular}{|c|c|c|c|c|c|c|c|c|c|c|c|c|}
\hline \multirow[b]{3}{*}{$\begin{array}{l}\text { Average surface } \\
\left(\mathrm{sq} \cdot \mathrm{m}^{2}\right)\end{array}$} & & & & \multicolumn{6}{|c|}{ Construction period } & & & \\
\hline & \multicolumn{3}{|c|}{$<1960$} & \multicolumn{3}{|c|}{$1960-1985$} & \multicolumn{3}{|c|}{ 1986-1995 } & \multicolumn{3}{|c|}{$>1995$} \\
\hline & 50 & 65.5 & 85 & 50 & 65.5 & 85 & 50 & 65.5 & 85 & 50 & 65.5 & 85 \\
\hline Zone I & 55 & 72 & 94 & 48 & 63 & 82 & 41 & 54 & 70 & 34 & 45 & 59 \\
\hline Zone II & 62 & 81 & 106 & 55 & 72 & 94 & 48 & 63 & 82 & 41 & 54 & 70 \\
\hline Zone III & 69 & 90 & 117 & 62 & 81 & 106 & 55 & 72 & 94 & 48 & 63 & 82 \\
\hline $\begin{array}{l}\text { Average sum } \\
\text { insured }\end{array}$ & 55.000 & 72.050 & 93.500 & 55.000 & 72.050 & 93.500 & 55.000 & 72.050 & 93.500 & 55.000 & 72.050 & 93.500 \\
\hline
\end{tabular}

$[=85$ sq. $\mathrm{m} \times € 400]$. These amounts represent the maximum insurance coverage for houses. It is noted that the maximum indemnification paid by the programme will be the amount that refers to building sum insured. If, for example, a 50 sq.m house suffers $€ 65.000$ material damages to building and contents, the indemnification paid will be up to $€ 55.000$. Contents sum insured is a sub limit of the total limit, which will be equal to the building sum insured. This split between insured values would help in the calculation of the indemnification in case of partial losses.

By applying the gross premium rates on insured properties, we find that gross premiums per house vary from $€ 34$ to $€ 117$, with an average of $€ 65$. Premiums are shown on Table 5. ${ }^{39}$ It is obvious that high risk zones and old houses pay the highest premium. A rational argument would be that this is not fair, as old houses would probably belong to low income citizens. But, on the other hand, the compulsory insurance programme secures insurance cover to owners of old houses, who would be rejected by insurance companies. This is the case for houses built before 1960, which amount to over 1,500,000 in Greece; even if they managed to have insurance access, the insured values would be much lower for a more expensive premium.

\section{Cash flow of insurance programme}

It is assumed that the programme insures at least 50 per cent of the houses in the first year of operation. For the following years, we assume an annual growth rate of 5 per cent. Under these assumptions, the programme would collect $€ 236$ million in gross premium, which after the expenses will amount to $€ 188$ million in net premium (no investment income is assigned). Table 6 presents an indicative 5-year operational cash flow plan for the programme. By the end of the fifth year, more than $€ 260$ million net premiums will be collected annually. Most of the annual revenue will be ceded to

\footnotetext{
${ }^{39}$ The insured portfolio is split according to surface, seismic zone and construction period. The variable for surface assumes the values: 50 sq.m, 85 sq.m. and their average value 65,5 sq.m. The sum insured is also calculated using these surface averages.
} 
Table 6 Indicative 5-year operational cash flow plan

\begin{tabular}{lccccc}
\hline Years & 1 & 2 & 3 & 4 & 5 \\
\hline Total no. of houses & $7,294,434$ & $7,294,434$ & $7,294,434$ & $7,294,434$ & $7,294,434$ \\
Expected \% of insured houses & $50 \%$ & $55 \%$ & $60 \%$ & $65 \%$ & $70 \%$ \\
Expected no. of policies & $3,647,217$ & $4,011,939$ & $4,376,660$ & $4,741,382$ & $5,106,104$ \\
Total net premiums received & $€ 188,646,377$ & $€ 207,511,015$ & $€ 226,375,653$ & $€ 245,240,291$ & $€ 264,104,928$ \\
Total gross premiums received & $€ 235,807,972$ & $€ 259,388,769$ & $€ 282,969,566$ & $€ 306,550,363$ & $€ 330,131,161$ \\
Policy fees (5\%) & $€ 9,432,319$ & $€ 10,375,551$ & $€ 11,318,783$ & $€ 12,262,015$ & $€ 13,205,246$ \\
Commissions paid to insurance & $€ 18,864,638$ & $€ 20,751,102$ & $€ 22,637,565$ & $€ 24,524,029$ & $€ 26,410,493$ \\
companies (10\%) & & & & & \\
Commissions paid to insurance & $€ 18,864,638$ & $€ 20,751,102$ & $€ 22,637,565$ & $€ 24,524,029$ & $€ 26,410,493$ \\
intermediaries (10\%) & & & & & \\
\hline
\end{tabular}

international reinsurers, but at a declining rate. If no major losses take place in the early years of the programme, then a substantial reserve will be built gradually.

\section{Risk financing issues}

The risk financing strategy optimises the relationship among premium levels, policy coverage and creditworthiness. The National Earthquake Insurance Programme could, initially, set the goal of being able to cover a 1-in-25 years event without becoming insolvent. This target should, later on, be extended to a return period of 1-in-100 years. From Figure 3 and Table 2, we derive that the first target requires that the insurance programme has a claim-paying capacity of about 5 billion euros; in the latter case, the claim-paying capacity of the programme is 14 billion euros.

But things may be easier in the most realistic case of Table 6 , where we assume that only half of the homeowners will be insured. Then, Tables 7 and 8 show that in the return period 1-in-50 years the claim-paying capacity of the system should be about 3 billion euros, whereas in the return period 1-in-100 years the capacity should increase to 4.6 billion euros.

Indeed, Table 7 shows that the total insured value of the insurance portfolio is $€ 284,842,203,250$, which is much less than the original value of the overall country portfolio. This is because the highest value per house is derived from the building sum insured which is caped at $€ 93,500$. By applying the PML percentages for gross losses from Table 2, we may get an estimate of the insured portfolio loss exposure, as shown on Table 8 .

A key issue to be addressed is the sourcing of the insurance programme's claimspaying capacity; in other words, a decision has to be made on the risk retention and the level of reinsurance. An initial conclusion arising from Table 8 is that for the first few years, the retention should be minimal and most of the premium should be used to buy reinsurance. Ideally, the programme should secure reinsurance cover in order to absorb losses incurred by a 1-in-200 years event; in such a case, the required reinsurance cover would amount to about 7 billion euros and would probably absorb all first year premiums. It is expected that this cover would be made available by the international reinsurance market without difficulty. The growth of the 
Table 7 Insured portfolio values

\begin{tabular}{|c|c|c|c|c|c|c|}
\hline $\begin{array}{l}\text { Average } \\
\text { surface } \\
\left(S q . m^{2}\right)\end{array}$ & 50 & 65.5 & 85 & 50 & 65.5 & 85 \\
\hline & \multicolumn{3}{|c|}{$<1960$} & \multicolumn{3}{|c|}{$1986-1995$} \\
\hline Zone 1 & $3,772,615,000$ & $9,698,542,425$ & $14,646,681,500$ & $3,046,395,000$ & $7,831,582,825$ & $11,827,235,750$ \\
\hline Zone 2 & $4,608,230,000$ & $9,125,204,550$ & $16,387,371,000$ & $2,668,352,500$ & $5,283,858,800$ & $9,488,987,750$ \\
\hline \multirow[t]{2}{*}{ Zone 3} & $276,237,500$ & $519,156,275$ & $771,608,750$ & $102,382,500$ & $192,409,525$ & $285,969,750$ \\
\hline & \multicolumn{3}{|c|}{$1960-1985$} & \multicolumn{3}{|c|}{$>1995$} \\
\hline Zone 1 & $11,696,657,500$ & $30,069,383,025$ & $45,410,659,250$ & $3,854,812,500$ & $9,909,829,050$ & $14,965,750,250$ \\
\hline Zone 2 & $7,303,312,500$ & $14,462,020,100$ & $25,971,401,500$ & $2,932,187,500$ & $5,806,293,350$ & $10,427,166,750$ \\
\hline Zone 3 & $149,902,500$ & $281,679,475$ & $418,693,000$ & $114,510,000$ & $215,213,350$ & $319,910,250$ \\
\hline
\end{tabular}

Table 8 Loss exposure of insured portfolio (gross losses)

\begin{tabular}{lccc}
\hline $\begin{array}{l}\text { Return } \\
\text { period }\end{array}$ & $\begin{array}{c}\text { Exceedance } \\
\text { probability }(\%)\end{array}$ & $\begin{array}{c}\text { PML as \% of total } \\
\text { value } \\
\text { (all models })(\%)\end{array}$ & $\begin{array}{c}\text { Gross losses } \\
\text { (at Insured portfolio; } \\
50 \% \text { of total portfolio) }\end{array}$ \\
\hline 1 in 5 years & 20 & 0.10 & $284,842,203$ \\
1 in 10 years & 10 & 0.30 & $854,526,610$ \\
1 in 25 years & 4 & 0.60 & $1,709,053,220$ \\
1 in 50 years & 2 & 1.00 & $2,848,422,033$ \\
1 in 100 years & 1 & 1.60 & $4,557,475,252$ \\
1 in 150 years & 0.67 & 2.00 & $5,696,844,065$ \\
1 in 200 years & 0.50 & 2.40 & $6,836,212,878$ \\
1 in 250 years & 0.40 & 2.70 & $7,690,739,488$ \\
1 in 500 years & 0.20 & 3.70 & $10,539,161,520$ \\
1 in 1,000 years & 0.10 & 4.80 & $13,672,425,756$ \\
\hline
\end{tabular}

programme in the following years will not only allow for a higher capacity, but will also lead to a reduction of ceded reinsurance premiums and, thus, to the rapid accumulation of a substantial reserve. In future, the target would be for a higher level of claims-paying capacity; for example, the California Earthquake Authority has a claims-paying capacity sufficient to withstand a 1-in-800 year event. A more realistic target for the Greek system would be to be able to survive a 1-in-250 year event.

A national earthquake insurance programme will also help in developing business for insurance carriers and intermediaries. The insurance industry will receive a very large volume of new businesses at no risk as the associated risk will be automatically transferred to reinsurance market via the National Earthquake Insurance Programme. For the service of this business, both insurance carriers and intermediaries will receive a significant amount of commissions. Also, the operation of the compulsory insurance programme will bring in new customers and new business to insurance companies and intermediaries. It is expected that a significant number of policy-holders will become aware of the earthquake risk and will require supplementary insurance. This insurance 
will be provided more easily by insurance companies as the compulsory insurance limits will act as a deductible to the voluntary insurance cover.

\section{Conclusions}

Although Greece is very vulnerable to earthquake hazard, there is no insurance plan in place that could absorb economic losses caused by an intensive seismic event. Most neighbouring countries have already developed catastrophe insurance organisations. It is suggested that Greece establishes and organises its own programme. The Turkish Catastrophe Insurance Programme could provide a useful precedent.

It has been shown in this paper that the potential damage from an earthquake could be devastating for Greece, as happened in 1999. By employing four different catastrophe models, we have estimated that the cost of a 1-in-200 years event is likely to be greater than 22 billion euros; for a 1-in-100 years event is about 14 billion euros; for a 1 -in-25 years event is 5 billion euros; and for a 1 -in-5 years event is 1.3 billion euros. This potential loss severity reveals the inherent limitations of the ex post funding approach to natural disasters adopted by successive Greek governments and underscores the urgent need for establishing a National Earthquake Insurance Programme.

The proposed National Earthquake Insurance Programme is a compulsory insurance programme based on the principle of a public-private partnership. The objectives of the programme would be: to provide affordable earthquake insurance, up to a maximum amount to all homeowners on the basis of risk-based premiums; to build a fund that is self-sustaining in the long run; to reduce the Government's obligation to provide post-disaster emergency relief to the owners of residential houses; and to provide strong incentives for ex ante mitigation of loss exposures.

Indemnification paid by the programme will be on a first loss basis. Premiums charged will be actuarially fair for homeowners and based on two parameters: construction year and seismic zone. The private insurance market will be rewarded by a commission for issuing policies and collecting premiums. It is very important that the programme commands adequate political support and the State is uncompromising regarding the payment of indemnifications to homeowners who refuse to be insured.

A preliminary financial analysis has shown that the programme is feasible in the short run, when most of the premium will be used to buy the necessary reinsurance cover; in the long run, the suggested earthquake insurance programme will be viable and will be able to accumulate substantial reserves. The long-term target of the management of the programme should be to secure enough insurance capacity to absorb expected losses even in 1-in-250 years events.

A national earthquake insurance programme will also help in developing business for insurance carriers and intermediaries. The new business will give a boost to the insurance market and will bring in new customers to insurance companies and intermediaries. The general public will become aware of the catastrophe risks and will 
search for supplementary insurance. The State will not be obliged to raise funds for post disaster relief and will, eventually, assume the role of the reinsurer of last resort.

A final issue concerns the current economic and political realities of Greece. A rational reaction to this issue is that the establishment of the proposed insurance programme is a real necessity exactly because of the current problems; on the one hand, no advance funding will be required by the State and on the other hand, the existence and operation of such a programme would alleviate the need for government financing in case of loss.

\section{Acknowledgement}

The authors thank two anonymous referees for their very useful comments that contributed to the improvement of the article.

\section{References}

AICG (2001) 'Association of insurance companies of Greece', Statistical Bulletin.

Best's Review, June 2011, 'Recipes for Disaster', pp. 30-33.

Bruggeman, V., Faure, M. and Fiore, K. (2010) 'The government as reinsurer of catastrophe risks', The Geneva Papers on Risk and Insurance - Issues and Practice 35(3): 369-390.

Coate, S. (1995) 'Altruism, the Samaritan's dilemma, and government transfer policy', American Economic Review 85(1) Q: 46-57.

Cole, C., Macpherson, D., Maroney, P., McCullough, K., Newman, J. and Nyce, C. (2011) 'The use of postloss financing of catastrophic risk', Risk Management and Insurance Review 14(2): 265-298.

Cummins, J.D., Doherty, N.A. and Lo, A. (2002) 'Can insurers pay for the «Big One»? Measuring the capacity of an insurance market to respond to catastrophic losses', Journal of Banking and Finance 26: $557-583$.

Cummins, D. (2006) 'Should the government provide insurance for catastrophes?' Federal Reserve Bank of St. Louis Review 88(4): 337-379.

Cummins, D. (2008) 'CAT bonds and other risk-linked securities: State of the market and recent developments', Risk Management and Insurance Review 11(1): 23-47.

Freeman, P. (2004) 'Government natural catastrophe insurance programs', paper presented at the OECD Conference on Catastrophic Risks and Insurance, 22-23 November 2004, Paris.

Froot, K. (2001) 'The market for catastrophe risk: A clinical examination', Journal of Financial Economics 60(2/3): 529-571.

GAO (2005) U.S. General Accounting Office Catastrophe risk: US and European approaches to insure natural catastrophes and terrorism risk', GAO-05-199. Washington, D.C.

Gollier, C. (2005) 'Some aspects of the economics of catastrophe risk insurance', in OECD (ed.) Catastrophic Risks and Insurance, Paris: OECD Publishing, pp. 13-30.

Grace, F.M., Klein, R.W. and Kleindorfer, P.R. (2000) 'The Demand for Homeowners Insurance with Bundled Catastrophe Coverages', Wharton Project on Managing Catastrophic Risks.

Gron, A. (1994) 'Capital constraints in property-casualty insurance markets', Rand Journal of Economics 25: $110-127$.

Grossi, P. and Kunreuther, H. (2005) Catastrophe Modelling: A New Approach to Managing Risk, HUEBNER International Series on Risk, Insurance and Economic Security, Springer, Boston.

Gurenko, E. (ed.) (2004) Catastrophe Risk and Reinsurance, London: Risk Books.

Gurenko, E., Lester, R., Mahul, O. and Gonulal, O.S. (2006) Earthquake Insurance in Turkey, History of the Turkish Catastrophe Insurance Pool, Washington, D.C.: The World Bank.

Gurenko, N.E. (2006) 'Building effective public private partnerships: A case study of the Turkish Catastrophe Insurance Pool', Insurance Instruments for Adaptation to Climate Risks, Expert Meeting, Vienna, Austria, 24-25 September 2006. 
Guy Carpenter (2010) 'World Catastrophe Reinsurance Market', New York: Guy Carpenter and Co.

Harrington, S. (2000) 'Rethinking disaster policy: Breaking the cycle of "free" disaster assistance, subsidized insurance, and risky behavior', Regulation 23: 40-46.

Institute of Geodynamics (2006) Earthquakes in Greece, Athens: Institute of Geodynamics.

Jaffee, D.M. and Russell, T. (1997) 'Catastrophe insurance, capital markets and uninsurable risks', The Journal of Risk and Insurance 64(2): 205-230.

Jaffee, D.M. and Russell, T. (2005) Should governments provide catastrophe insurance? Center for Real Estate and Urban Economics, University of California, Berkeley, Paper 296.

Jongejan, R. and Barrieu, P. (2008) 'Insuring large-scale floods in the Netherlands', The Geneva Papers on Risk and Insurance-Issues and Practice 33(2): 250-268.

Kleffner, A. and Doherty, N.A. (1996) 'Costly risk bearing and the supply of catastrophic insurance', Journal of Risk and Insurance 63: 657-671.

Kleindorfer, P. and Kunreuther, H. (1999) 'Challenges facing the insurance industry in managing catastrophic risks', in K. Froot (ed.) The Financing of Property/Casualty Risks, Chicago: University of Chicago Press.

Kunreuther, H. (1984) 'Causes of underinsurance against natural disasters', The Geneva Papers on Risk and Insurance-Issues and Practice 31: 206-220.

Kunreuther, H. (1996) 'Mitigation disaster losses through insurance', Journal of Risk and Uncertainty 12: 171-187.

Kunreuther, H., Ginsberg, R., Miller, L., Sagi, P., Slovic, P., Borkay, B. and Katz, N. (1978) Disaster Insurance Protection: Public Policy Lessons, New York: John Wiley and Sons.

Kunreuther, H. and Pauly, M. (2006) 'Rules rather than discretion: Lessons from Hurricane Katrina', Journal of Risk and Uncertainty 33: 101-116.

Lewis, C.M. and Murdock, K.C. (1996) 'The role of government contracts in discretionary reinsurance markets for natural disasters', The Journal of Risk and Insurance (Symposium on Catastrophic Risk), 63(4): 567-597.

Lewis, T. and Nickerson, D. (1989) 'Self insurance against natural disasters', Journal of Environmental Economics and Management 16: 209-223.

Litan, R. (2006a) 'What is the appropriate role of the federal government in the private markets for credit and insurance? What is the outlook?' Federal Reserve Bank of St. Louis Review 88(4): 387-390.

Litan, R. (2006b) Sharing and Reducing the Financial Risks of Future "Mega-catastrophes", Issues in Economic Policy, Washington, D.C.: The Brookings Institution.

Monti, A. and Chiaves, F. (2006) 'Italy', in M. Faure and T. Hatlief (eds.) Financial Compensation for Victims of Catastrophes: A Comparative Legal Approach, Vienna: Springer, pp. 145-194.

National Observatory of Athens, from http://www.gein.noa.gr.

NAIC (2009) 'National Association of Insurance Commissioners: Natural Catastrope Risks: Creating a comprehensive National Plan'.

NSSG (December 2000) 'National statistical service of Greece', The Census of Year 2000.

Nektarios, M. (2011) 'A catastrophe insurance system for the European Union', Asian-Pacific Journal of Risk and Insurance 5(2). Article 6, doi: 10.2202/2153-3792-1109.

OECD (2005) 'Organization for economic co-operation and development', 'Catastrophe Risks and Insurance', OECD Policy Issues in Insurance. No 8. Paris.

Picard, P. (2008) 'Natural disaster insurance and the equity-efficiency trade-off', Journal of Risk and Insurance 75(1): 17-38.

Priest, G. (1996) 'The government, the market and the problem of catastrophe loss', Journal of Risk and Uncertainty 12: 219-237.

Slovic, P. (2000) The Perception of Risk, London: Earthscan Publications.

Thieken, A., Petrow, T., Kreibich, H. and Merz, B. (2006) 'Insurability and mitigation of flood losses in private households in Germany', Risk Analysis 26: 383-395.

Tsapanos, T.M. and Burton, P.W. (1991) 'Seismic hazard evaluation for specific seismic regions of the world', Tectonophysics 194: 153-169.

Zeckhauser, R. (1995) 'Insurance and catastrophes', The Geneva Papers on Risk and Insurance-Issues and Practice 20: 157-175. 


\section{About the Authors}

Aglaia Petseti is a $\mathrm{PhD}$ candidate at the Department of Statistics and Insurance, University of Piraeus, Greece.

Milton Nektarios is Associate Professor of Insurance at the Department of Statistics and Insurance, University of Piraeus, Greece. His main research interests are in applied insurance issues, catastrophe risks and pension systems. He was formerly the CEO of Ethniki Insurance Company and Governor of the Social Insurance Organisation of Greece. 